\title{
TDO2 Gene
}

National Cancer Institute

\section{Source}

National Cancer Institute. TDO2 Gene. NCI Thesaurus. Code C39669.

This gene plays a role in tryptophan catabolism. 